\title{
A Preliminary Study of Uterine Derived Polymorphonuclear Cell Function in Mares with Chronic Uterine Infections
}

\author{
By Mats Troedsson, Carlos Concha, Stig Einarsson and Olof Holmberg
}

Department of Obstetrics and Gynaecology, Swedish University of Agricultural Sciences, National Veterinary Institute and Department of Veterinary Microbiology, Swedish University of Agricultural Sciences, Uppsala, Sweden.

\begin{abstract}
Troedsson, M., C. Concha, S. Einarsson and O. Holmberg: A preliminary study of uterine derived polymorphonuclear cell function in mares with chronic uterine infections. Acta vet. scand. 1990, 31, 187-192. - From 6 mares with chronic uterine infection, polymorphonuclear neutrophils (PMNs) were obtained from the uterus. In order to recover an adequate number of viable PMNs, $0.1 \%$ oyster glycogen was infused into the uterus as a mild irritant $12 \mathrm{~h}$ prior to the uterine flushing.

Phagocytosis and chemotaxis of the uterine derived PMNs were determined. The supernatant from the uterine flushing was compared with autologous serum for its capacity as an opsonin and chemoatractant. There was a significant increase of both phagocytosis and chemotaxis when autologous serum was used compared with the supernatant from the uterine flushing.

This study indicates that autologous serum has a greater opsonizing capacity than uterine secretion from mares with chronic uterine infection. Since all mares conceived following this study, the use of oyster glycogen was not considered to have deleterious effect on the uterine mucosa.
\end{abstract}

horse; uterus; phagocytosis; chemotaxis.

\section{Introduction}

Chronic uterine infections is a common cause of subfertility in the mare. It is diagnosed on the basis of history, clinical examination, uterine culture, cytology and biopsy. Even if these mares are treated with appropriate antibiotics until negative on bacterial culture, the inflammation will not heal completely and the mares remain susceptible to uterine infection. A defect in the local uterine defense mechanism is thought to be responsible for this susceptibility (Asbury et al. 1984, Cheung et al. 1985, Liu et al. 1985).

Several studies of mares susceptible to chronic uterine infections, have shown a dysfunction of uterine polymorphonuclear neu- trophils (PMNs) to migrate, phagocytize and kill ingested material, when compared to resistant mares (Asbury et al. 1982, Cheung et al. 1985, Liu et al. 1985). This functional defect could either be due to a dysfunction in the PMNs themselves or to an insufficient opsonisation in the uterus. Some encouraging results reported when susceptible mares were treated with local infusion of plasma in the uterus emphasized insufficient opsonisation as a possible cause of chronic uterine infections (Asbury et al. 1984). Though increased amount of immunoglobulin (IgG, IgA and IgM) has been found in uterine washings from mares susceptible to uterine infections when compared to resistant mares (Asbury et al. 1980, Mitchell et 
al. 1982, Williamson et al. 1983), a lack of complement in uterine secretion was suggested to be responsible for the insufficient opsonisation in the uterus (Asbury et al. 1984). However, conflicting results have been reported (Hansen \& Asbury 1987) and the exact mechanism behind the dysfunctional local uterine immune response in mares susceptible to chronic uterine infections remains unknown.

The purpose of this study was to develop a non-harmful method to derive cells associated with inflammatory reactions from the uterus in mares with chronic uterine infections. The opsonizing capacity and chemoattractant properties of the supernatant from the uterine flushing was compared with that of autologous serum.

\section{Material and methods}

This study included 6 mares (5 standardbred and 1 thoroughbred) with a history of infertility for at least the last 2 breeding seasons. The mares were sampled for uterine cytology, bacterial cultures and uterine biopsies. The uterine biopsies were divided into 3 categories as described by Kenney (1975) where grade 1 indicates normal uterine morphology and grade 3 indicates chronic inflammation and fibrosis. Blood samples were collected from the jugular vein, to determine the total and differential white blood cell counts.

\section{Uterine washings}

In order to stimulate PMN migration into the uterine lumen, $100 \mathrm{ml} 0.1 \%$ oyster glycogen, a mild irritant, was infused $12 \mathrm{~h}$ before the sampling. A total of $500 \mathrm{ml}$ of a phosphate-buffered saline solution, $\mathrm{pH} 7.2$ (PBS), containing 40 IU oxytocin, was flushed into the uterus using a modified Foley catheter. After a brief massage of the uterus through the rectum, the washings were al- lowed to flow into a sterile flask by gravity. The uterine washing was immediately transported to the laboratory and PMN function tests were performed within $2 \mathrm{~h}$ after each sampling.

The washings were centrifuged at $2000 \mathrm{rpm}$ for $20 \mathrm{~min}$ and the cell pellets were resuspended in a smaller amount of PBS. Total number and cell viability was determined by the tryphan blue exclusion test (Barta et al. 1984). The total number of PMNs in uterine washings was determined by examining acridine orange stained cells in a fluorescence microscope (Enright \& Jeffers 1984).

Chemiluminescence: An indirect measure of phagocytosis

The phagocytic capacity of the uterine derived PMNs was analyzed using chemiluminescence (Washburn et al. 1982). Zymosan (Sigma) was used as a phagozytizing substrate. The opsonic capacity of uterine larvage was compared with that of autologous serum. A solution containing $0.6 \mathrm{ml}$ autologous serum and $0.2 \mathrm{ml}$ PBS was added to $10 \mathrm{mg}$ zymosan. In a parallel test $0.8 \mathrm{ml}$ of the supernatant was added to $10 \mathrm{mg}$ of $\mathrm{zy}$ mosan. The resulting solutions were incubated in a $37^{\circ} \mathrm{C}$ water bath for $30 \mathrm{~min}$. Opsonized zymosan particles were washed twice and resuspended to the original volume in PBS. One hundred $\mu \mathrm{l}$ of $2 \times 10^{6} \mathrm{PMNs} / \mathrm{ml}$ PBS, $500 \mu$ l PBS, $200 \mu$ l opsonized zymosan, in either serum or the supernatant from the uterine washing, and $200 \mu \mathrm{l}\left(10^{-4} \mathrm{M}\right)$ luminol was added to a disposable sample cuvette. Chemiluminescence generated by the PMN was measured in a Luminometer ${ }^{\circledR}$ (Model 1251, LKB, Sweden).

\section{Chemotaxis}

Chemotaxis was measured using a multiwell filter chemotactic chamber model described by Axelsson et al. (1981). Plastic microcen- 
Table 1. Results of endometrial biopsies, cultures, cytology and the number of viable polymorphonuclear neutrophils (PMNs) obtained from uterine washings of 6 mares with uterine infections.

\begin{tabular}{|c|c|c|c|c|}
\hline Mare no. & $\begin{array}{l}\text { Biopsy } \\
\text { grade*) }\end{array}$ & Bacterial culture & Cytology & $\begin{array}{l}\text { Total no. of cells/ } \\
\% \text { viable PMNs }\end{array}$ \\
\hline 1 & 2 & Escherichia coli & - & $\begin{array}{l}274 \times 10^{6} \\
90 \%\end{array}$ \\
\hline 2 & 2 & Streptococcus zooepidemicus & + & $\begin{array}{l}40 \times 10^{6} \\
70 \%\end{array}$ \\
\hline 3 & 2 & Klebsiella species & - & $\begin{array}{l}46 \times 10^{6} \\
80 \%\end{array}$ \\
\hline 4 & 2 & 0 & + & $\begin{array}{l}100 \times 10^{6} \\
80 \%\end{array}$ \\
\hline 5 & 2 & Streptococcus zooepidemicus & - & $\begin{array}{l}55 \times 10^{6} \\
90 \%\end{array}$ \\
\hline 6 & 2 & Actinomyces pyogenes & + & $\begin{array}{l}200 \times 10^{6} \\
65 \%\end{array}$ \\
\hline
\end{tabular}

*) according to Kenney (1975).

trifuge tubes were placed in the wells of the lower compartment of the chambers. A total amount of $400 \mu \mathrm{l}$ autologous serum or supernatant from the uterine washing was used as chemoatractant. Unstimulated migration was measured by adding $400 \mu \mathrm{l}$ of a saline solution instead of a chemoatractant. Micro filters were placed over the wells and the top of the chambers was put in a place. A total of $4 \times 10^{5}$ PMNs was added to the upper chamber compartment, above the filters. After incubation in $30^{\circ} \mathrm{C}$ for $60 \mathrm{~min}$, the filters were stained, removed from the chemotactic chambers and fixed on slides. Migration was determined in triplicate using the method described by Zigmond \& Hirsch (1973) and expressed as the mean distance migration in 5 microscopic fields per filter.

\section{Results}

The results of cytology, bacteriological culture and endometrial biopsies are shown in Table 1. PMNs were present in large amounts in the uterine smears from mares no. 2, 4 and 6 while the rest of the mares only showed epithelial cells in the smears.
All the mares except no. 4 tested positive on bacteriologic cultures. The endometrial biopsies categorized all the mares as grade 2 . The total and differentiated white blood cell count from venous blood samples were within the normal range in all of the mares.

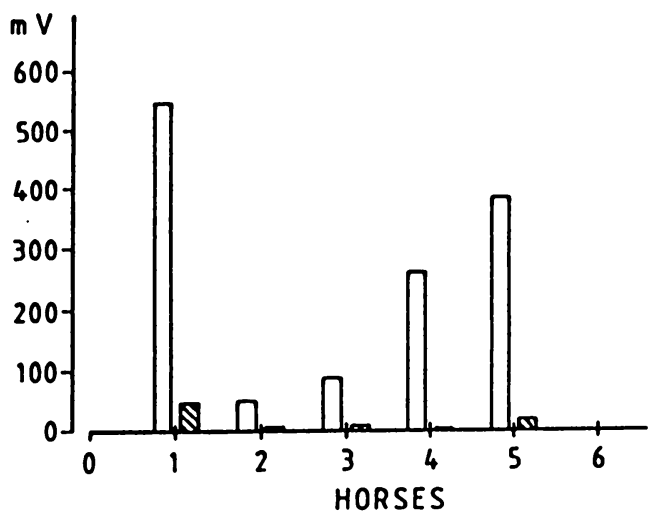

Figure 1. The phagocytic capacity, determined with chemiluminescence, of uterine derived polymorphonuclear neutrophils (PMNs) from mares with chronic uterine infections. Autologous serum (open bars) and the supernatant from uterine washings (striped bars) were used for opsonisation. 


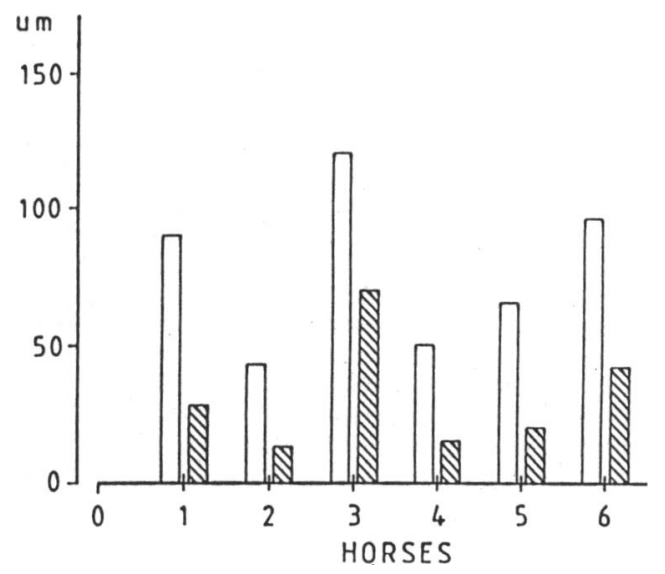

Figure 2. Chemotactic capacity of uterine derived polymorphonuclear neutrophils (PMNs) from mares with chronic uterine infections. Autologous serum (open bars) and the supernatant from uterine washings (striped bars) were used as chemoatractants.

The total number of cells derived from the uterine washings varied from $40 \times 10^{6}$ to $274 \times 10^{6}$ and $65-90 \%$ of the cells were viable.

The capacity of the uterine derived PMNs to phagocytize zymosan after opsonisation with autologous serum and the supernatant from the uterine washing is shown in Fig. 1. There was a significant increase in phagocytosis when zymosan was opsonized in serum compared to the supernatant $(\mathrm{p}<0.05$, paired t-test). No results are available for the phagocytic capacity of mare no. 6 , due to errors in processing the samples.

Chemotaxis is shown in Table 2. Chemotaxis of uterine derived PMNs increased in all the mares when serum was used as chemoatractant compared to the supernatant ( $p<0.01$, paired t-test).

\section{Discussion}

The method that was used to derive an adequate amount of viable PMNs from the uterus in the mares and test methods used to analyze phagocytosis (using chemiluminescence) and chemotaxis (using migrationchemotactic chambers) worked satisfactory. All the mares were treated for their uterine infections and became pregnant during the same breeding season. The pregnancies progressed normally during the 9 weeks the mares were monitored in all except 1 of the mares that resorbed her embryo around day 40. Hence our conclusion is that the technique used to derive PMNs from the uterus is safe and does not cause any damage to the endometrium.

The bactericidal capacity of uterine derived PMNs increased significantly after opsonisation of zymosan particals with serum compared to supernatant from the uterine washing. The supernatant was used as a model for the uterine secretion. Since the uterine washings was diluted with PBS, the autologous serum was also diluted $(0.2 \mathrm{ml}$ PBS to $0.6 \mathrm{ml}$ serum) before opsonisation. However the dilutions of uterine washings were most likely higher and varied between samples. This could have affected the results but could probably not completely explain the large differences between serum and uterine washings observed.

The chemotactic capacity of uterine derived PMNs did also show significant differences depending on if serum or supernatant was used as chemoatractant.

This study indicates that serum has a positive effect on the function of PMNs with regard to both chemotaxis and bactericidal activity. The exact mechanism behind this effect is not known. Nevertheless, the fact that autologous serum has this positive effect on the local immune response in the uterus, is of great importance for the understanding of different treatment regimes of mares with chronic uterine infections. The mechanism behind serum's positive influence on chemotaxis and phagocytosis should be further investigated. 


\section{Acknowledgements}

This study was supported by the Swedish Racing Board (ATG). The authors would like to thank Skråmsta, Eriksund and Rävdansens studfarms for providing us with horses, Dr. Kerstin Darenius for her interpretation of uterine biopsies and Maria Fredriksson for skilful technical assistance.

\section{References}

Asbury $A C$, Halliwell REW, Foster $G W$, Longino $S J$ : Immunoglobulins in uterine secretions of mares with differing resistance to endometritis. Theriogenology 1980, 14, 299-308.

Asbury AC, Schultz KT, Klesius PH, Foster GW, Washburn SM: Factors affecting phagocytosis of bacteria by neutrophils in the mare's uterus. J. Reprod. Fert. Suppl. 32, 1982, 151-159. Asbury AC, Gorman NT, Foster GW: Uterine defense mechanisms in the mare: serum opsonins affecting phagocytosis of Streptococcus zooepidemicus by equine neutrophils. Theriogenology 1984, 21, 375-385.

Axelsson LG, Nilsson G, Björksten B: Statistical aspects of cell motility determinations with a modified chemotaxis assembly for multiwell filter assays. J. Immunol. Methods 1981, 46, 251-258.

Barta $O$, Shaffer LM, Huanz LJ: Separations of lymphocytes, monocytes and neutrophils. In: Laboratory Techniques of Veterinary Clinical Immunology, ed. Barta, Springfield, Illinois 1984 , pp. 31-42.

Cheung ATW, Liu IKM, Walsh EM, Miller ME: Phagocytic and killing capacities of uterine derived polymorphonuclear leukocytes from mares resistant and susceptible to chronic endometritis. Amer. J. vet. Res. 1985, 46, 19381940.

Enright FM, Jeffers $G W$ : Function tests for mononuclear phagocytes. In: Laboratory Techniques of Veterinary Clinical Immunology, Ed. Barta, Springfield, Illinois 1984, pp. 58-64.

Hansen PJ, Asbury AC: Opsonins of Streptococcus in uterine flushings of mares susceptible and resistant to endometritis: Control of secretion and partial characterization. Amer. J. vet. Res. 1987, 48, 646-650.
Kenney RM: Prognostic value of endometrial biopsy in the mare. J. Reprod. Fert. Suppl. 23, 1975, 347-348.

Liu, IKM, Cheung ATW, Walsh EM, Miller ME, Lindenberg PM: Comparison of periphera! blood and uterine derived polymorphonuclear leucocytes from mares resistant and susceptible to chronic endometritis: Chemotactic and cell elastimetry analysis. Amer. J. vet. Res. 1985, 46, 917-920.

Mitchell G, Liu IKM, Perryman LE, Stabenfeldt $G$, Hughes JP: Preferential production and secretion of immunoglobulins by the equine endometrium - a mucosal immune system. J. Reprod. Fert. Suppl. 32, 1982, 161-168.

Washburn SM, Klesius PH, Ganjham VK: Characterization of the chemiluminescence response of equine phagocytes. Amer. J. vet. Res. 1982, 43, 1147-1151.

Williamson $P$, Dunning A, O'Connor J, Penhale $W J$ : Immunoglobulin levels, protein concentrations and alkaline phosphatase activity in uterine flushings from mares with endometritis. Theriogenology 1983, 19, 441-448.

Zigmond SH, Hirsch JG: Leukocyte locomotion and chemotaxis. J. exp. Med. 1973, 136, 387410.

\section{Sammanfattning}

En preliminär studie av cellfunktionen hos neutrofila granulocyter frän livmodern hos ston med kronisk livmoderinfektion.

Från 6 ston med kronisk livmoderinfektion samlades neutrofila granulocyter från livmodern. För att fa ett tillräckligt antal levande neutrofila granulocyter infunderades $0.1 \%$-ig oyster glycogen i livmodern, som ett svagt irritationsmedel 12 timmar före livmodersköljningen. Fagocytos och kemotaxis bestämdes hos neutrofila granulocyter från livmodern. Supernatanten från livmodersköljningen jämfördes med autologt serum avseende opsoniserande och kemotaktiska förmåga. Det var en signifikant ökning av fagocytos och kemotaxis när autologt serum användes jämfört med supernatanten från livmodersköljningen. Denna studie indikerar att serum har en positiv effekt på fagocy- 
tos och kemotaxis hos neutrofila granulocyter från livmodern i jämförelse med livmodersekret från ston med kronisk livmoderinfektion. Då alla ston blev dräktiga efter detta experiment ansågs användningen av oyster glykogen inte ha någon skadlig effekt på livmoderns slemhinna.

(Received July 16, 1989; accepted September 11, 1989).

Reprints may be requested from: Stig Einarsson, Department of Obstetrics and Gynaecology, Swedish University of Agricultural Sciences, P. O. Box 7039, S-750 07 Uppsala, Sweden. 